\title{
Role Conflict between Land Allocation and Municipal Functions in Addis Ababa
}

\begin{abstract}
The current accelerated growth of Addis Ababa has caused tension between the favourable aspects of urban redevelopment, and the corresponding wake-up calls against the risks of transforming various parts of the city into haphazard 'concrete jungle'. I argue that there is role conflict in municipality authorities that are entrusted with the power to lease out urban land, and at the same time carry out the regulatory function of revising and implementing urban master plans and providing municipal services. It is argued that the land provision function of municipalities (and their corresponding interest in enhancing revenue from lease) induces them to lease out urban land to the detriment of green areas, neighborhood play fields, public parks, open spaces, riverbanks, street alignments and adequate space for bus and taxi terminals (menaheria). Such role conflict not only enhances administrative discretion and corruption, but also weakens urban land holding security, represses municipal services and adversely affects the propriety and effectiveness of urban plans.
\end{abstract}

Elias N. Stebek *

\section{Key words}

Property rights, role conflict, land rights, urban plan, expropriation, municipal services, Addis Ababa.

DOI http://dx.doi.org/10.4314/mlr.v7i2.3

\section{Introduction}

The commendable pace of urban redevelopment in Addis Ababa including infrastructure improvements evokes mixed feelings of appreciation vis-à-vis concerns for the adverse impact of declining open spaces and steadily increasing

* LL.B, LL.M, PhD; Associate Professor, St. Mary’s University, School of Graduate Studies. Email: elstebek@gmail.com, eliasnr@smuc.edu.et

Some parts of this article are improved versions of sections in the second and fifth chapters of the research titled "Property Rights Protection and Private Sector Development in Ethiopia" which was submitted to Private Sector Development Hub at the Ethiopian Chamber of Commerce and Sectoral Associations. The author is grateful to Private Sector Development Hub for sponsoring the research in partnership with SIDA (Swedish International Development Cooperation Agency). I am also grateful to the two anonymous reviewers for their comments on the earlier draft of the article. 
problems related with urban utilities, waste management, transport management, noise pollution, glaze, sewerage, and alternating extremes of urban warming and floods. Undoubtedly, urban redevelopment in the context of Addis Ababa and other Ethiopian cities is expedient. But a caveat that should accompany this pursuit is the concern for a holistic conception of wellbeing which recognizes the physical, psychological, economic, social and environmental dimensions of 'good urban life' in sustainable cities.

In legal regimes which recognize transfers in land rights as a predominantly private pursuit, municipalities merely play their conventional roles in urban planning, urban plan implementation and municipal services such as urban utilities (i.e., water supply, electricity, etc.), waste disposal, green area management, and many others. In other words, municipalities are custodians of the utilities (such as water supply and electricity), streets, parks, open spaces, etc. of the city they administer, and are not providers of land for construction. The intervention of the state under such circumstances is minimal, other than measures of expropriation for 'public purpose' such as roads and other public utilities, and few incidences of intervention to facilitate 'efficient' utilization of urban land resources.

The other extreme relates to what was experienced in various countries as a result of 'Marxist' policies. Under this setting, the state intervened as the custodian of public property including urban land. However, land allocation was based on grants (and not lease sale), thereby rendering it usually insusceptible to conflict of interest between generating revenue through land allocation and commitment to a sound master plan. This is because land market was considered irrelevant in soviet-model command economies while on the contrary, the absence of land markets in a market-driven economy causes the inefficient allocation of land and loss of government tax revenue from private sales transactions. ${ }^{1}$

The function of municipalities in Ethiopia varies from the aforementioned two scenarios because it creates vested interest in municipalities to generate revenue from urban leasehold allocation of land which conflicts with their roles as sources and custodians of urban master plan and as entities that are expected to give prime attention to municipal services (in ensuring water supply, electricity, waste management, public parks, green areas, efficient transportation, and other public needs and amenities). It is against this backdrop that the following sections examine the conflict of interest on the part of municipal authorities in Addis Ababa which are in the midst of role conflict

\footnotetext{
${ }^{1}$ Li, L., \& Isaac, D. (1999). Development of urban land policies in China. In J. J. Chen \& D. Wills (Eds.), The impact of China's economic reforms upon land, property and construction (p. 17). Aldershot, England: Ashgate Publishing Ltd.
} 
between their interest in enhancing revenue from land lease and their municipal responsibilities of implementing urban master plans and providing municipal services.

The first section highlights the need for balancing the tension between the transfer of urban land to its most efficient user and the equity to which the persons who are being dispossessed should be entitled. Section 2 examines whether the Ethiopian legal regime restricts the economic value of home ownership to roofs and walls. Sections 3 and 4 briefly discuss the challenges of administrative discretion in the definition of "public purpose", urban plan revision, expropriation, complaint procedures, compensation and examples of arbitrary revocation of title deeds. Section 5 highlights the role conflict between Addis Ababa Municipality's functions as custodian of the city's master plan and as the provider of land on leasehold sales. And finally a brief reflection on the 'problem tree' is made in the sixth section.

\section{Equity, Efficiency and Property Rights in the Context of Urban Redevelopment: An Overview}

\subsection{The balance between rational self-interest and public interest}

Economic development involves the private sector, the public sector and a third sector which does not fall under the two categories. The latter includes civil societies, non-governmental institutions/organizations and social/cultural/ religious entities. These three sectors operate with the citizenry/populace as their foundation, which can be regarded as their raison d'être. The extent to which people are informed and engaged (as participants and beneficiaries) thus determines the degree of achievements in these three sectors.

The functions and objectives of these three sectors have reinforcing correlation within the context of commonalities and variation. The pursuits of the entities address (a) the interest of private persons; and (b) social interest that transcends and at the same time facilitates the realization of private interests. Rational self-interest is expected to be driven by the needs, values, behaviours and pragmatic desires of the individual person. This is accompanied by the wider context and setting of public interest (such as the common good or shared aspirations) which facilitates the fulfillment of a 'rational' individual's selfinterest. The issue of property rights is relevant from both dimensions.

Property rights have been subject of discourse from extremist and pragmatic perspectives. On the one hand, there is an overstretched conception of 'do as you please' interpretation in which the private individual or the legal person behaves as the master of natural resources, while the other extreme takes an acrimonious stance against private property. The latter runs the risk of elite capture by paternalistic authorities who consider themselves as 'custodians of 
public property' and expose public property to 'rent seeking greed', unregulated/unprotected open access and 'the tragedy of the commons'.

The protection of private property rights thus involves managing the tension between the protection of rational self-interest of individuals (and companies), and at the same time ensuring the enhancement of public interest. The pull factors in this tension involve the extremist version of property rights claims, and/or the other extreme of paternalistic administrative discretion which may lead to arbitrary bestowal and withdrawal of property rights without judicial scrutiny.

Safeguards against these extremes lie on the schemes that control and harness both tendencies so that (a) private property rights can be protected without meanwhile being abused by the right holders; and (b) the stakes of the public are taken care of with due caveat against 'elite capture' which may be engaged in 'rent seeking' predatory pursuits in the guise of 'public interest'. Enabling factors such as good governance and institutional settings become crucial in the quest for the avoidance of these pitfalls that emanate from the two extremes.

As Krueckeberg notes, property is not merely an "object of possession or capital in isolation, but a set of relationships between the owner of a thing and everyone else's claim to the same thing". ${ }^{3}$ Such understanding of property "highlights considerations of distributive justice that are particularly important in light of the issues in the contemporary debate about property rights". 4

The land use rights of a person is fundamental to the individual, while at the same time there can be the consideration of social wellbeing which might necessitate expropriation for public use. This has "always been subject to reasonable constraints for the benefits of the entire community and society". Moreover, there might also be land reallocation for a more efficient use of urban

2 The concept of the 'tragedy of the commons' was formulated by Garett Hardin in 1968, Science, New Series, Vol. 162, No. 3859. (Dec. 13, 1968), pp. 1243-1248. It states that the competition among members of a community to augment one's use of a resource that is held in common leads to overconsumption and dissipation. It is based the assumption that what is commonly owned will be eventually overexploited and degraded. This assumption should not, however mean that common property or shared access to resources invariably encounters this tragedy, because rules of sustainable use can be established among the right holders in common property accompanied by the denial of access to others. See for example, Feeny et al "The Tragedy of the Commons: Twenty-Two Years Later" Human Ecology, Vol. 18, No. 1 (Mar., 1990), pp. 1-19.

${ }^{3}$ D. Krueckeberg (1995). 'The difficult character of property: to whom do things belong', Journal of the American Planning Association, Vol. 1, No. 61, pp. 301-9.

${ }^{4}$ Ibid

${ }^{5}$ Ibid. 
land. This calls for a balance that can accommodate both interests in such a manner that equity in favour of the owner is maintained in the course of land allocation towards its most efficient utility.

\section{2- Striking the balance between 'equity' and 'efficiency'}

The property rights regime is among the areas of the law which are considerably altered in the course of social change. The fundamental changes made in Ethiopia's property law regime since the mid-1970s have caused ambiguities in interpreting the scope of property rights on immovable property. In light of the changes that were witnessed since 1975, Ethiopia's property law regime has gone through fundamental transformations which have brought about various issues that are susceptible to different perspectives of interpretation. In particular, misconceptions that undermine the scope of landholding rights in the context of public ownership have been conducive to a very narrow definition of land use rights. There is thus the need for rethinking beyond the walls and roofs in the valuation of urban house ownership.

A person who owns an urban house in Ethiopia has ownership right over the premises and use right over the land (subject to the duration of lease in case of lease holds). On the other hand, urban redevelopment necessitates the utilization of urban land by the most efficient user. This creates tension and harmony between 'equity' in favour of urban house owners vis-à-vis the 'efficient' use of land towards urban redevelopment through reallocation of land to developers. The extent to which these objectives are balanced through win-win schemes can protect the weaker party from inequitable trade-offs. In the Ethiopian context, the core issue is whether the law should only allow compensation for the corporeal elements of the house that is demolished upon expropriation such as walls and roofs, or for the wider right that includes incorporeal land use rights.

The discussion herein on the 'equity' and 'efficiency' balance does not need deeper theoretical engagement on themes such as the Pareto Efficiency Criterion, named after Vilfredo Pareto (1848-1923) nor the Kaldor-Hicks efficiency criterion which "corresponds with the utilitarian-ethical policy alternative" as proposed by economists Kaldor (1939) and Hicks (1939)". "The former argues against a policy alternative which "makes any member of society worse off than under the status quo". The latter theory suggests that "we must compute net social utility (adding up the gains and the losses for each member of society) for each policy alternative to the status quo" so that the policy

\footnotetext{
${ }^{6}$ See Elias N. Stebek (2012). The Investment Promotion and Environment Protection Balance in Ethiopia's Floriculture: The Global Value Chain in Focus, PhD Thesis, University of Warwick School of Law, pp. 78, 79.

${ }^{7}$ Id., p. 78.
} 
alternative that generates the largest gain in net social utility "can be taken as the efficient policy alternative". 8

Discussion on the theory of 'efficiency' is outside the scope of this article, because the need for the most efficient use of land in urban redevelopment is apparent. On the other hand, however, 'Equity' requires respect for the property rights, interests and wellbeing of urban homeowners. Arguments in favour of fair procedures and equitable compensation do not negate the transfer of land to more efficient users, and are not as rigid as the Pareto Criterion in the definition of 'efficiency'. This criterion "is problematic as it indirectly protects the status quo because it is difficult to come up with a policy alternative that would satisfy every member of a given society". 9

The social benefits of 'efficient' utilization of urban land, i.e. economic efficiency include their positive contribution in the supply of goods and services such as residential and office premises that can be rented to a significant number of end-users. The issue that arises in relation with these competing interests is whether one of them needs to be traded-off in favour of the other. While 'equity' requires fair, prompt and adequate compensation commensurate with the current value of the property, the rationale of economic efficiency and productivity warrants assigning land to investors who would optimize the economic and social utility of the land which benefits not only the individual investors but the society at large. The issue that arises is whether there can be a win-win synthesis of equity-cum-efficiency in the course of reassigning urban land holding rights.

Urban redevelopment projects encounter various challenges. One of the challenges is the definition of 'public interest' ${ }^{\text {'0 }}$ and 'public purpose'. As highlighted in Section 3.1, 'public interest' is given a very wide meaning under the Urban Lands Lease Holding Proclamation No. 721/2011. Section 4.1 further shows that the term 'public purpose' embodies a relatively similar meaning under Proclamation No. 455/2005. ${ }^{11}$ In both proclamations, the meaning given to 'public purpose' is broader than the traditional 'for-public-use project' definition such as highways, public parks, schools, public hospitals and the like.

Roads, electric lines, public parks, street alignments, etc. benefit (and are accessible to) the public at large. Urban redevelopment projects that have these objectives are apparently of public interest. According to the 1960 Ethiopian Civil Code "the creation of land or streets"12 can justify expropriation. Likewise, the relevant authorities "may, by way of alignment" take measures of

\footnotetext{
${ }^{8}$ Id., pp. 78, 79.

${ }^{9}$ Id., p. 78.

${ }^{10}$ Article 2(7), Urban Lands Lease Holding Proclamation No. 721/2011.

11 The Expropriation of Landholdings for Public Purposes and Payment of Compensation Proclamation No. 455/2005, Art. 2(5).

12 Article 1450(1), Ethiopian Civil Code.
} 
expropriation in order "to widen or straighten existing roads or streets".13 Likewise, Proclamation No. 401/2004 ${ }^{14}$ (which is repealed by Proclamation No. $455 / 2005$ ) had pursued the traditional narrow interpretation of works carried out in the public interest as the sole grounds for expropriation.

This meaning of 'public interest' or 'public purpose' under the Civil Code of 1960 and under Proclamation No. 401/2004 did not cover the eviction of urban house owners from a certain location in Addis Ababa in order to reassign the land to an investor. No doubt, the new investment may not only entail profit for the investor, but may also bring about employment, tax revenue and other economic benefits. Based on such social utility, one can argue in favour of using the land for an investment project. However, this argument relates to 'efficient' use of resources which is different from expropriation for 'public purpose', a concept that needs restrictive interpretation.

Yet, not all 'investments' bring about positive economic and social benefits to the community. A case in point is reallocation of land that surrounds a lake to residential resorts or similar purposes without leaving a public walking path around the lake. Under such circumstances few 'investors' are allowed to have access to their boats and the lake, while the entire population and all potential tourists (of the current generation and the generations yet to come) are denied of the right to walk around the lake. Setting aside such speculative land acquisitions and rent gathering, the issue that needs to be addressed is whether there can be modalities that strike a balance between enhancing the efficient use of land in urban redevelopment and at the same time avoid inequitable eviction of land holders.

Meanwhile, it is worth to note that holdouts by landholders (who seek overstated compensation unwarranted by the market price of their land use rights and the premises on the land) hamper urban redevelopment. This does not, however, justify the other extreme of under-compensation upon eviction. The considerations of 'equity' and 'efficiency' are thus principles that should be pursued without trade-offs. Even though undermining the need for the utmost 'efficient' use of urban land adversely affects urban development, mere focus on this pursuit by setting aside 'equity' in relation with the property rights of urban landholders becomes single-faceted and violates property rights. As Scully observes, "[e]conomic progress and equity are not incompatible. Nations can move to a less restrictive rights regime and increase economic efficiency,

\footnotetext{
${ }^{13}$ Article 1450(2), Ethiopian Civil Code.

${ }^{14}$ Appropriation of Land for Government Works and Payment of Compensation for Property Proclamation No. 401/2004, Article 2.
} 
economic growth, and equity". 15 The following section examines whether Ethiopian law justifies trade-offs against 'equity'.

\section{Property Rights beyond the Walls and Roofs}

\subsection{Constitutional provisions on land use rights}

Although land is publicly owned, pursuant to Article 40(3) of the Ethiopian Constitution $^{16}$, Article 40(1) stipulates that "Every Ethiopian citizen has the right to the ownership of private property." Subject to the prescriptions of the law and public interest, Article 40(1) guarantees, "the right to acquire, to use and, in a manner compatible with the rights of other citizens, to dispose of such property by sale or bequest or transfer it otherwise." The definition of private property under the Constitution ${ }^{17}$ envisages "tangible or intangible product which has value and produced by the labour, creativity, enterprise or capital of an individual [... or a legal person]" or, "in appropriate circumstances, by communities specifically empowered by law to own property in common." The Constitution regards private property of individuals and legal persons as the product of one's "labour, creativity, enterprise or capital", and it also envisages the legal recognition of community ownership."

Subject to the public ownership of land, Article 40(6) of the Constitution recognizes the land use rights of private investors "on the basis of payment arrangements as established by law" and the provision states that the "[p]articulars shall be determined by law". ${ }^{18}$ This constitutional recognition of land use rights accorded to investors extends to other citizens as well. For example, Articles $40(4)^{19}$ and $40(5)^{20}$ of the Constitution guarantee the land use

${ }^{15}$ Gerald W. Scully (1991). "Rights, Equity, and Economic Efficiency", Public Choice, Vol. 68, No. 1/3 (Jan., 1991), p. 212.

${ }^{16}$ Article 40(1) of the Constitution of the Federal Democratic Republic of Ethiopia reads: "The right to ownership of rural and urban land, as well as of all natural resources, is exclusively vested in the State and in the peoples of Ethiopia. Land is a common property of the Nations, Nationalities and Peoples of Ethiopia and shall not be subject to sale or to other means of exchange."

${ }_{18}^{17}$ FDRE Constitution, Art. 40(2).

18 The provision reads "Without prejudice to the right of Ethiopian Nations, Nationalities, and Peoples to the ownership of land, government shall ensure the right of private investors to the use of land on the basis of payment arrangements established by law. Particulars shall be determined by law."

19 "Ethiopian peasants have right to obtain land without payment and the protection against eviction from their possession. The implementation of this provision shall be specified by law." 
rights of smallholder farmers and pastoralists. The joint reading of sub-Articles 4, 5 and 6 of Article 40 of the Constitution shows that land use rights have constitutional recognition in Ethiopia.

Moreover, a careful reading of Article 40(7), second sentence, shows that the right of an owner of an immovable property goes beyond the property that $\mathrm{s} / \mathrm{he}$ has built and the permanent improvements made on the land. The provision reads:

Every Ethiopian shall have the full right to the immovable property he builds and to the permanent improvements he brings about on the land by his labour or capital. This right shall include the right to alienate, to bequeath, and, where the right of use expires, to remove his property, transfer his title, or claim compensation for it. Particulars shall be determined by law. [Italics added]

The phrase "where the right of use expires, to remove his property" clearly shows that a house owner's rights can be restricted to the property on the land only when the duration of the land use right expires. This, in other words, recognizes the entitlement of an urban homeowner not only to the property on the land, but also to land use right, which apparently has economic value.

\subsection{Urban land use rights -versus- mere holding and usufruct}

The elements of ownership embodied in continental legal systems are the right to use (usus), the right to enjoy the fruits (fructus), and the right to dispose of (abusus). Article 1205 of the Ethiopian Civil Code ${ }^{21}$ has adopted this approach.

The land use right which can be claimed by the urban house owner goes beyond mere holding on behalf of the state or the government, because a holder (as envisaged in the Civil Code) possesses a thing on behalf of another owner or possessor. ${ }^{22}$ Although leaseholding does not confer ownership rights over the land, it is not exclusively restricted to 'usus' (short of enjoying the fruits of ownership) because the leaseholder is entitled to construct buildings on the land and then own the buildings during the period of lease.

20 "Ethiopian pastoralists have the right to free land for grazing and cultivation as well as the right not to be displaced from their own lands. The implementation shall be specified by law."

${ }^{21}$ Article 1205 states the scope of ownership rights. Sub-Article 1 states the scope of the right to use and exploit property, and Sub-Article 2 recognizes the right to dispose of property 'for consideration or gratuitously.'

${ }^{22}$ See for example Civil Code, Arts. 1141, 1147. 
In spite of current restrictions on transfer of leasehold under Proclamation No. $721 / 2011^{23}$ on which a certain level of construction is not made, leasehold over land is not a restrictive use right (mere usus) comparable to a tenant's use right of a house s/he has rented from the owner. Instead, it is an expansive use right which includes the right to use, develop and exploit the land. Leasehold over urban land thus confers a wider right than usufruct under the Civil Code. ${ }^{24}$ Article 24 of the Lease Proclamation ${ }^{25}$ can also be cited in this regard because it recognizes the right to transfer or pledge leasehold rights under the circumstances stipulated in the provision.

The owner of an urban house is regarded as the owner of the building, and at the same time, as the possessor of the land based on leasehold or old possession. ${ }^{26}$ In effect, property rights of urban house owners go beyond claims over the roofs and walls, but should also extend to the economic value of their rights to use the land. Upon expropriation, equity thus requires compensation not only to the roofs and walls, but also to the land use rights that are being transferred to the new holder.

The tension discussed in the preceding section between the considerations of 'equity' and 'efficiency' can be addressed by taking the market value received from the investor per square meter as a threshold. This amount should thus go to the landholder because it is not the public ownership over the land that is transferred, but the use right of the evictee. In other words, the principle of 'efficiency' cannot justify the denial of compensation (commensurate with the market price paid by investors to municipal authorities) for the land use rights that a house owner loses.

\subsection{Strong land use rights and the issue of enhanced re- development cost}

Some writers argue that imperfect property rights can be conducive to the transfer of property to more efficient users ${ }^{27}$ with relatively low investment cost. Proponents of this view state that the exposure of investors to heavy compensation adversely affects the momentum and dynamism of investment.

${ }^{23}$ The restriction under Article 24 et al of Urban Lands Lease Holding Proclamation No. 721/2011 is meant to control speculative land transfers which are susceptible to corruption.

${ }^{24}$ See Civil Code, Articles 1309-1358 for the rights in usufruct.

${ }^{25}$ Urban Lands Lease Holding Proclamation No. 721/2011.

${ }^{26}$ Article 2(18) of the Urban Lands Lease Holding Proclamation No. 721/2011 defines 'old possession' as "a plot of land legally acquired before the urban center entered into the leasehold system or a land provided as compensation in kind to persons evicted from old possession."

${ }^{27}$ See for example, Schmid, A (2008). An Institutional Economic Perspective on Economic Growth (Michigan Institute University Paper). 
China is cited as an example for the benefits of relatively easier eviction owing to public ownership of land and the relatively modest levels of compensation to urban and rural landholders.

As Zhang observes, however, property rights in China are not imperfect with regard to the protection accorded to investors. He argues that even if there was initially weaker protection of land use rights upon the eviction of landholders, widespread discontent impedes long term development. ${ }^{28}$ This was soon realized, and China's property rights protection regime is steadily strengthened particularly since the enactment the 2007 Chinese Property law.

The fact that most houses are government owned in Ethiopia makes it unlikely that compensation for the reallocation of land use rights based on the lease rates becomes a hindrance to urban redevelopment. It is to be noted that the need for striking a balance between 'equity' and 'efficiency' not only involves fair compensation and due process in favour of evictees, but also requires due protection against 'holdouts' from some landholders who may demand unrealistically overstated payments. Such encounters can be resolved by making reference to the price offered per square meter in the vicinity or comparable location during the preceding months. The most difficult challenge in the Ethiopian context is not thus the risk of such 'holdouts' but the tendency to trade-off 'equity' by administrative authorities that are, as the following sections indicate, vested with discretionary powers.

\section{Avenues of Administrative Discretion}

\subsection{The definition of 'public purpose' and its susceptibility to arbitrary revision of urban plans}

The definition of "public purpose" embodied in Proclamation No. 721/2011 is very wide and susceptible to administrative discretion. The Proclamation defines 'public purpose' as 'the use of land defined as such by the decision of the appropriate body in conformity with urban plan in order to ensure the interest of the people to acquire direct or indirect benefits from the use of the land and to consolidate sustainable socio-economic development". ${ }^{29}$ This definition has the following four cumulative elements:

(a) an appropriate body (i.e. municipality) can decide whether a certain use of urban land constitutes 'public purpose'; and,

(b) the decision should be made in conformity with urban plan; and

${ }^{28}$ Xiaobo Zhang (2006). Asymmetric Property Rights in China's Economic Growth, Paper presented at the session on "Land Rights and Social Security in China" of the Annual American Economics Association Meetings, Boston, January 6-8, 2006. International Food Policy Research Institute (IFPRI).

${ }^{29}$ Urban Lands Lease Holding Proclamation No. 721/2011, Art. 2(7). 
(c) ensure the interest of people to acquire direct or indirect benefits from the use of the land, and

(d) consolidate sustainable socio-economic development.

The first and second elements raise queries related with the modalities of the issuance, revision and implementation of urban plan. ${ }^{30}$ Where there is a master plan with long-term perspectives, urban plan can be said to be predictable, proactive and visionary. On the other hand, if a city mainly develops haphazardly, urban plans can be significantly dictated by unfolding realties of urban growth and administrative decisions rather than serving as proactive blueprints for structural and local urban development that consider prospective urban development needs including future transportation and utility expansions.

According to the Urban Planning Proclamation No. 574/2008, the purposes of urban planning include control against "the proliferation of unplanned urban centers" which should be "regulated and guided by sound and visionary urban plans to bring about balanced and integrated national, regional and local development"; and "the carrying out of development undertakings in urban centers", in such a manner that "they will not be detrimental to the general wellbeing of the community as well as the protection of natural environment". 31

These basic principles enshrined in the preamble of Proclamation No. $574 / 2008$ are further substantiated by the basic principles embodied in Article $5^{32}$ which include:

- the promotion of balanced and mixed population distribution;

- safeguarding the community and the environment;

- preservation and restoration of historical and cultural heritages;

- balancing public and private interests; and

- ensuring sustainable development.

The Proclamation envisages city-wide structural plan ${ }^{33}$ and local development plans ${ }^{34}$. The structural plan, inter alia, shows "the magnitude and direction of growth of the urban center", "principal land use classes", "housing development"; "the layout and organization of major physical and social infrastructure", "urban redevelopment intervention areas", "environmental aspects" and industry zone". "As stipulated under Article 11(3) of the

${ }^{30}$ Art. 2(8) of Proclamation No. 721/2011 defines urban plan as "structural plan, local development plan or basic plan of an urban center including annexed descriptive documents which are legally endorsed by the authorized body and have legally binding effect."

${ }^{31}$ Urban Planning Proclamation No. 574/2008, Paragraphs 1 and 3 of the Preamble.

${ }^{32}$ Id., Art. 5, Sub-Articles 6 to 10.

${ }^{33}$ Id., Art. 8(1).

${ }^{34}$ Id., Art. 8(2).

${ }^{35}$ Id., Art. 9(2). 
Proclamation, local development plans give further details regarding the master plan and shall, as appropriate, state:

a) zoning of use type, building height and density;

b) local streets and layout of basic infrastructure;

c) organization of transport system;

d) housing typology and neighborhood organization;

e) urban renewal, upgrading and reallocation intervention areas; and

f) green areas, open spaces, water bodies, and places that might be utilized for common benefits.

Structural plans are valid for ten years ${ }^{36}$ and local development plans are "implemented within the validity period of the structure plan". ${ }^{37}$ The power to formally initiate urban plans is vested upon "chartered cities and urban administrations as well as the concerned regional and federal authorities" ${ }^{38}$ Pursuant to Article 14 of the Proclamation, urban centers 39 "at all levels shall have the power and duty to prepare and review or cause the preparation and review of their respective structure and local development plans by certified private consultants or public institutions" and the provision further states that the particulars shall be determined by law.

After the preparation of the final draft of structure and local development plans, they shall be deliberated upon and approved by [city] councils and communicated to the concerned regional or federal authorities", 40 subject to the possibility of revision by the federal or regional governments ${ }^{41}$ in the event of non-conformity with the requirements set forth under Proclamation No. $574 / 2008$. Upon approval, chartered cities or urban administrations shall implement the structure and local development plans, ${ }^{42}$ in the course of which they are empowered to "dispossess urban land holdings against paying compensation". ${ }^{43}$

Urban centers are also empowered to revise and modify the structure and urban plans ${ }^{44}$ after the expiry of the plan implementation period ${ }^{45}$ or before the

\footnotetext{
36 Id., Art. 10.

${ }^{37}$ Id., Art. 12.

${ }^{38}$ Id., Art. 13(3).

39 According to Art. 2(8) of Proclamation No. 574/2008 "Urban Center means any locality with established municipality or having a population size of 2000 or above inhabitants, of which $50 \%$ of its labor force is primarily engaged in non-agricultural activities."

40 Proclamation No. 574/2008, Art. 16(1).

${ }^{41}$ Id., Art. 16(2).

42 Id., Art. 20.

${ }^{43}$ Id., Art. 20(2).

${ }^{44}$ Id., Art. 23.

${ }^{45}$ Id., Art. 22(1).
} 
expiry of this period of implementation "if the need arises". 46 Moreover, urban plans that are approved "may be modified with regard to a portion of an urban center where the need arises". ${ }^{47}$ In the process of performing their urban redevelopment functions, administrative entities thus assume tasks of urban (master) plan revisions.

The preceding paragraphs show that municipalities are empowered to initiate, approve, implement, revise and modify city master plans which include structure and local development plans. An institution that is empowered to provide land on leasehold sales ${ }^{48}$ is at the same time empowered to approve, implement and modify urban master plans. This dual function is susceptible to undue compromises against commitment to the urban master plan under the

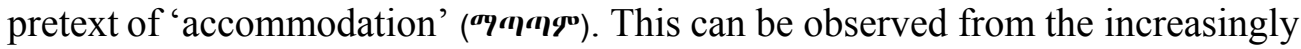
dwindling riverbanks, open spaces and green areas of Addis Ababa. Cases in point are:

- constructions in riverbanks such as one of the tallest buildings in Addis Ababa at the entrance of Ghion Hotel,

- the big mosque under construction in a riverbank at Afincho Ber,

- premises rented out for boutiques, cafés and shops which are mushrooming

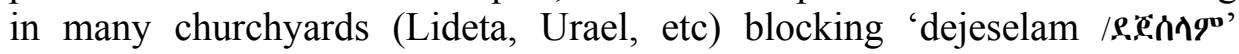
(spiritual moments of believers and slight bows while passing by churches),

- the heavy concrete concentration at Kazanchis which clearly proves the impact of haphazard rush to augment revenue from lease sales to the detriment of the municipal functions of maintaining balance between builtup areas and open spaces,

- blocked view of Yeka Mountain's green landscape by constructions such as Belle View Hotel, the ten-storey building at the foothills of the mountain (which faces Diaspora Square /Megenagna), ${ }^{49}$

- and many others.

Urban planning is required to ensure that houses (including their exterior paints) can melt into a harmonic landscape without disturbing its surroundings. ${ }^{50}$ On the contrary, the examples stated above violate the objectives enshrined in

${ }^{46}$ Id., Art. 22(2).

${ }^{47}$ Id., Art. 22(3).

${ }^{48}$ The city administration is vested with the power to lease out land under the Urban Lands Lease Holding Proclamation No. 721/2011. See for example, Articles 4, 8-11, 14, 16-20, etc.

49 Constructions on such locations should be rare, and in the event of exceptional permissions, the premises should have been a maximum of ground plus one with adequate frontal space and gardening to conserve the landscape greenery.

${ }^{50}$ See for example, $<$ http://www.havsvidden.com/en/cliff-houses $>$, Accessed: 15 December 2013. 
Proclamation No. 574/2008 because the Proclamation aims at urban development "regulated and guided by sound and visionary urban plans to bring about balanced and integrated national, regional and local development" commensurate with the requirements of "the general wellbeing of the community as well as the protection of natural environment". 52

\section{2 'Public purpose' as ground of expropriation}

As stated in the introductory paragraphs of Section 3.1, the third and fourth elements in the definition of public purpose under Article 2(7) of the Urban Lands Lease Holding Proclamation No. 721/2011 relate the definition of 'public purpose' with "the interest of people to acquire direct or indirect benefits from the use of the land", and "sustainable socio-economic development". The phrase 'direct or indirect benefits' is susceptible to a very wide interpretation, while the phrase "sustainable socio-economic development" can easily be watered down by administrative authorities even if its definition envisages the economic, social and environmental dimensions of urban development in the context of good governance.

Proclamation No. 721/2011 empowers the Ministry of Urban Development and Construction to "prepare model regulations, directives and manuals to be issued for the implementation of this Proclamation". ${ }^{53}$ Moreover, "Regions and city administrations shall have the powers and duties to (1) administer land, in all urban centers ..."; and (2) issue regulations and directives necessary for the implementation of [the] Proclamation". ${ }^{4}$

Such powers to administer land and to issue regulations can entail abuse of power if there are gaps in harnessing the rulemaking and administrative function of these administrative entities. These gaps exacerbate administrative discretion and abuse owing to the conflict of interest involved in the functions of administrative authorities that are entrusted with rule making, adjudication (of administrative complaints) and implementation of the same without adequate judicial scrutiny and in the absence of administrative procedural law which is yet a draft since $2001 .^{55}$

Article 40(8) of the FDRE Constitution provides that "[w]ithout prejudice to the right to private property, the government may expropriate private property for public purposes subject to payment in advance of compensation commensurate to the value of the property". The definition of 'public purpose' is one of the factors that determine the scope of administrative entities in the

${ }^{51}$ Proclamation No. 574/2008, Preamble 1.

${ }^{52}$ Id., Preamble 3.

${ }_{54}^{53}$ Proclamation No. 721/2011, Art. 32(5).

${ }^{54}$ Ibid, Art. 33.

${ }^{55}$ The Draft Federal Administrative Procedure Proclamation, Justice and Legal Systems Research Institute, 2001, (Unpublished). 
course of expropriation. Proclamation No. 455/2005 defines public purpose as follows:

'public purpose' means the use of land defined as such by the decision of the appropriate body in conformity with urban structure plan or development plan in order to ensure the interest of the peoples to acquire direct or indirect benefits from the use of the land and to consolidate sustainable socioeconomic development. ${ }^{56}$

This definition is nearly identical with the definition given to 'public interest' in Article 2(7) the Urban Lands Lease Holding Proclamation No. 721/2011. As discussed earlier, the ambiguities in the definition of 'direct and indirect benefits' render arbitrary definitions of 'public purpose' possible thereby adversely affecting property rights. Article 3(1) of Proclamation No. 455/2005 gives a wide definition of 'public purpose' in the context of urban centers. It reads:

A woreda or an urban administration shall, upon payment in advance of compensation in accordance with this Proclamation, have the power to expropriate rural or urban landholdings for public purpose where it believes that it should be used for a better development project to be carried out by public entities, private investors, cooperative societies or other organs, or where such expropriation has been decided by the appropriate higher regional or federal government organ for the same purpose.

Belief by a woreda or urban administration that a rural or urban landholding "should be used for a better development project to be carried out by public entities, private investors, cooperative societies or other organs" can thus constitute public purpose thereby rendering the definition contingent upon the 'belief' of administrative entities rather than clearly articulated objective thresholds that define 'public purpose'. This definition is also problematic because it renders privately owned houses vulnerable if, for example, there is an attractive leasehold price which predominantly goes into the accounts of the municipality rather than its full transfer to the evicted homeowner as compensation.

Even if the same definition of 'public purpose' applies for all forms of landholding, Article 3(2) of Proclamation No. 455/2005 gives a relatively favourable exception to leaseholds. It reads: "[n]otwithstanding the provisions of Sub-Article (I) of [Article 3], no land leaseholding may be expropriated unless the lessee has failed to honor the obligations he assumed under the Lease Proclamation and Regulations or [unless] the land is required for development works to be undertaken by government."

${ }^{56}$ The Expropriation of Landholdings for Public Purposes and Payment of Compensation Proclamation No. 455/2005, Art. 2(5). 
This exception uses two standards in the application of public purpose as defined in the proclamation. Land held under old possessions (which include a significant portion or urban land in Ethiopia), is subjected to the wider application of the definition of 'public purpose'. In contrast, the definition of 'public purpose' embodied in the proclamation applies to leasehold only if the leasee fails "to honor the obligations he assumed under the Lease Proclamation and Regulations or the land is required for development works to be undertaken by government. ${ }^{, 57}$ However, unlike Article 3(2) of Proclamation No. 455/2005 which gives a relatively favourable exception to leaseholds (as opposed to old possessions) in the definition of public purpose, Article 25(1)(b) of the Lease Proclamation No. 721/2011 does not make such restriction in the definition of 'public interest' for the purpose of termination of leasehold.

\subsection{Notification, property valuation, compensation and complaint procedures}

Notification of expropriation is made in writing by the woreda or urban administration that has decided to expropriate a landholding, and the notification states "the time when the land has to be vacated and the amount of compensation to be paid". ${ }^{58}$ The time for handing over the land to be vacated may extend until ninety days ${ }^{59}$, and shall not exceed 30 (thirty) days from the date of receipt of expropriation order "where there is no crop, perennial crop or other property on the expropriated land" ${ }^{60}$ In case "a landholder who has been served with an expropriation order refuses to handover the land within the period specified in Sub-Article (3) or (4) of [Article 4], the woreda or urban administration may use police force to take over the land". ${ }^{61}$

The basis and amount of compensation including displacement compensation are stipulated under Articles 7 and 8 of the Proclamation while Articles 10 and 11 deal with the modalities of valuation and complaint procedures. The compensation paid to the landholder covers the property on the land and permanent improvements made to the land. " ${ }^{62}$ "The amount of compensation for property situated on the expropriated land shall be determined on the basis of

${ }^{57}$ It is, however, to be noted that an act of reclaiming the leasehold right by a city administration upon a leasee's failure to honor the lease agreement does not constitute expropriation.

${ }_{59}^{58}$ Id., Art. Article 4(1).

${ }^{59}$ Id., Art. Art. 4(3). The days will be counted from "the date of payment of compensation or, if he refuses to receive the payment, from the date of deposit of the compensation in a blocked bank account in the name of the woreda or urban administration as may be appropriate."

${ }^{60}$ Id., Art. Art. 4(4).

${ }^{61}$ Id., Art. Art. 4(5).

${ }^{62}$ Id., Art. Art. 7(1). 
replacement cost of the property". ${ }^{63}$ The amount paid as "compensation for permanent improvement to land shall be equal to the value of capital and labour expended on the land" ${ }^{64}$ These provisions have substantially reduced the amount of compensation that was provided under Article 1474(1) of the Civil Code which provides that "[t]he amount of compensation or the value of the land that may be given to replace the expropriated land shall be equal to the amount of the actual damage caused by expropriation".

Article 26 of the Urban Lands Leasehold Proclamation states the power of the appropriate body ${ }^{65}$ with regard to clearing and taking over urban land. Article 26(1) provides that the appropriate body "shall have the power, where it is in the public interest, to clear and take over urban land upon payment of commensurate compensation, in advance, for the properties to be removed from the land". The person displaced "shall be provided with a substitute plot of land within the urban centre the size of which shall be determined by the region or the city administration". ${ }^{66}$ The provision, i.e. Article 26, further deals with clearance upon default in violation of the various terms in lease contracts ${ }^{67}$ and illegally occupied urban land. ${ }^{68}$

The possessor of the land displaced under Art. 26(1) is served written clearing order which states "the time the land has to be vacated, the amount of compensation to be paid and the size and locality of the substitute plot of land to be availed" ${ }^{69}$ The period of notification shall not be less than 90 days. $^{70}$ Grievances may be submitted to the body which has rendered the clearing order "within 15 working days after receipt of the order", ${ }^{71}$ and appeal can further be lodged to the Urban Land Clearing and Compensation Cases Appellate Tribunal. ${ }^{72}$ The tribunal shall be "accountable to the council of the region or the city administration" $" 73$ and it "may not be governed by the provisions of the ordinary Civil Procedure Code while conducting its functions". ${ }^{74}$

${ }^{63}$ Id., Art. Art. 7(2).

${ }^{64}$ Id., Art. Art. 7(4).

${ }^{65}$ Art. 2(6) of Proclamation No. 721/2011 defines 'appropriate body' as "a body of a region or a city administration vested with the power to administer and develop urban land."

${ }^{66}$ Proclamation No. 721/2011, Art. 26(2)

${ }^{67}$ Id., Art. 26(3).

${ }^{68}$ Id., Art. 26(4).

${ }^{69}$ Id., Art. 27(1).

${ }^{70}$ Id., Art. 27(2).

${ }^{71}$ Id., Art. 28(1).

72 Id., Arts. 29, 30.

${ }^{73}$ Art. 30(3).

${ }^{74}$ Art. 30(8). 
The decision of the Land Clearance Appeals Commission is final except for compensation. The finality clause embodied in the proclamation allows the aggrieved party to lodge an appeal only on the issue of compensation subject to "the right to file petition to the Cassation Division of the Federal Supreme Court if there is fundamental error of law". 75

The word 'yehizb (public ownership)' as used for rural land in Proclamation. No 31, 1975, ${ }^{76}$ and 'yemengist (government ownership)' as used for urban land in Proclamation No. 47/1975 77 may seem to imply variation in the content of the use rights". ${ }^{78}$ However, the Constitution does make such distinction between the scope of rural and urban land use rights.

As discussed in Section 1, the efficient use of urban land calls for urban redevelopment, and meanwhile, there is the need for win-win packages in which evicted persons should be fully paid the amount that is earned by the municipality. Such win-win schemes, however, require changes in Ethiopia's expropriation legal regime which should recognize compensation commensurate with the location value of the land use rights that are reallocated to another leaseholder. This requires the recognition of the economic value of a landholder's use rights and the periodic enhanced value of such rights which should be fully compensated upon expropriation.

This evokes the issue whether the economic value of a landholder's use rights is recognized under the Constitution. As highlighted under Section 2.1, Article 40(3) of the Constitution can be interpreted as bestowing bare ownership to the state if the use right over the land is held by a person who possesses the land. In fact, the land use rights of a landholder in Ethiopia goes beyond the elements of usus and fructus (stated above) because the right embodies some elements of abusus as land use rights can be transferred through inheritance and other means stated in the law. ${ }^{79}$

The notion of public ownership of land clearly needs pragmatic and purposive interpretation beyond its narrow literal interpretation. As Daniel Weldegebriel states:

Today, whether in urban or rural areas of Ethiopia, huge amount of land is being expropriated for urban redevelopment, urban expansion, road

75 Focus group discussion summary, 13 July 2013. The Focus Group Discussion on "Property Rights Protection and Private Sector Development in Ethiopia" was sponsored by the Private Sector Development Hub, Ethiopian Chamber of Commerce and Sectoral Associations.

${ }^{76}$ Public Ownership of Rural Lands Proclamation No 31/1975.

${ }^{77}$ Government Ownership of Urban Lands and Extra Houses Proclamation No. 47/1975

${ }^{78}$ Ato Muluneh Wordofa, President, Addis Ababa Land Clearance Appeals Commission (.Focus group discussion summary, supra note 75 .

${ }^{79}$ See for example Article 24 of Proclamation No. 721/2011. 
construction and other public activities. The valuation method adopted in the expropriation proclamation (Proclamation No. 455/2005) has a basic [flaw] in implementing the constitutional principle of payment of 'commensurate' amount. In urban areas, location has no value and owners are being compensated only the 'replacement cost' of buildings; government reaps the location value that was developed and grew at the expense of the land holder/dweller. ... The usual criticism on the practice is that compensation is not adequate; does not reflect the market value at all; and does not follow the constitutional guarantee provided to land rights. ${ }^{80}$

Daniel $^{81}$ compares lease bid advertised in Bole area as can be seen from newspapers which can be over 4 million Birr for 500 square meters vis-à-vis the amount paid to the owner of the house which can be around Birr 400,000 (Four Hundred Thousand). The following illustrates the margin of economic value of land use rights that landholders are denied upon reallocation of the urban land:

... [A]n owner of a hotel wished to purchase a neighboring land (small residential house) to use it as parking lot. He offered the owner 300,000 birr for the house but the owner refused to sell her property. The hotel owner, afterwards, applied for expropriation of the neighboring land in order to expand his parking lots. Accordingly, the respective urban land administration started expropriation process and acquired the land for the hotel owner upon payment of 60,000 birr, one fifth of the previously offered price. $^{82}$

Yoseph Aemero notes that "property rights should not be restrictively interpreted to mean fixtures to the land. The person who uses land has use rights that will be terminated due to expropriation, and this should also be considered during expropriation". ${ }^{83}$ Instead of compensation commensurate with the value of the use right on the land, an urban landholder shall, upon expropriation, be entitled to "a plot of urban land, the size of which shall be determined by the

${ }^{80}$ Daniel Woldegbriel Ambaye (2012). "Land Rights in Ethiopia: Ownership, equity, and liberty in land use rights", FIG Working Week 2012, available at $<$ http://www.fig.net/pub/fig2012/papers/ts02d/TS02D_ambaye_5521.pdf $>$

${ }^{81}$ Daniel WoldeGebriel, Bahir Dar University, Institute of Land Administration (Focus group discussion summary), 13 July 2013, supra note 75.

82 Daniel Woldegebriel (2013). Land Rights and Expropriation in Ethiopia, $\mathrm{PhD}$ Thesis, Real Estate Planning and Land Law, Department of Real Estate and Construction Management, School of Architecture and the Built Environment Royal Institute of Technology (KTH), Sweden. p. 214.

${ }^{83}$ Yoseph Aemero, Former High Court Judge, Currently Attorney and Consultant at Law (Focus group discussion summary), 13 July 2013. supra note 75. 
urban administration, to be used for the construction of a dwelling house" $" 84$ and a displacement compensation "equivalent to the estimated annual rent of the demolished dwelling house or be allowed to reside, [free] of charge, for one year in a comparable dwelling house owned by the urban administration" ${ }^{85}$ These entitlements for a plot of land and displacement compensation shall also apply mutatis mutandis to houses used for business undertakings. ${ }^{86}$

There are many types of loss that are not considered in the process of compensation. The valuation is not thus appropriate. In addition to the enhanced value of the land use rights and location value that are left unconsidered, there are also indirect losses (such as trade loss) due to trade interruptions as a result of the expropriation process. ${ }^{87}$

Valuation of the property situated on expropriated rural land is done by "a committee of not more than five experts having the relevant qualification to be designated by the woreda administration". ${ }^{88}$ In the case of urban land expropriation as well, the urban administration designates a committee of experts with the relevant qualification for the valuation of the property on the land. ${ }^{89}$ The level of expertise, fairness and impartiality observed in the process of valuation is thus debatable.

Council of Ministers Regulations No. $135 / 2007^{90}$ has been enacted to implement the provisions that deal with compensation under Proclamation No. $455 / 2005$. It provides for the determination of the amount of compensation in the case of total or partial demolition of buildings. ${ }^{91}$ Article 13 of the Regulations further provides a formula for the calculation of the compensation for buildings and relocated buildings. The provision of replacement of urban land is, however, "governed by directives issued by Regional States in accordance with Article 14 (2) of the Proclamation". 92 Although such replacement is commendable, the problem lies in its failure to distinguish between the economic values of the land expropriated and the land that is provided as replacement. Another challenge in this regard relates to the delay in the replacement of urban land.

${ }^{84}$ Expropriation of Landholdings for Public Purposes and Payment of Compensation Proclamation No. 455/2005, Art. 8(4)(a).

${ }^{85}$ Id., Art. Art. 8(4)(b).

${ }^{86}$ Id., Art. Art. 8(5).

${ }^{87}$ Daniel Woldegebriel, Bahir Dar University, Institute of Land Administration (Focus group discussion summary), 13 July 2013, supra note 75.

${ }^{88}$ Id., Art. Art. 10(1).

${ }^{89}$ Id., Art. Art. 10(2).

${ }^{90}$ Payment o f Compensation for Property Situated on Landholdings Expropriated for Public Purposes, Council of Ministers Regulations No. 135/2007.

${ }^{91}$ Id., Art. 3.

${ }^{92}$ Id., Art. 14. 
Good practice that can be noted at this juncture relates to the encouragement and support given to members of the business community (such as shop owners in Merkato area) to have leasehold by forming a private limited company, contribute capital, and build their premises according to the city's master plan. Under these schemes, the property rights of shop owners who had rented shops from the Agency for Government Houses are enhanced toward leasehold and this indeed facilitates private sector development.

Under Proclamation No. 455/2005, complaint is lodged to "the administrative organ established by the urban administration to hear grievances related to urban landholdings" if a "holder of an expropriated urban landholding is dissatisfied with the amount of compensation". 93 It is to be noted that the issue that can be contested is unduly restricted to the inadequacy of compensation. In addition to such restriction, "a complaint relating to the amount of compensation shall be submitted to the regular court having jurisdiction" can be made only if "an administrative organ to hear grievances related to urban landholding is not yet established". ${ }^{44}$ The submission of the complaint to courts of law is thus the exception rather than the rule. This does not, of course, restrict the aggrieved person from appealing to regular courts.

Article 11 of the Proclamation further stipulates appellate procedures for compensation which "as may be appropriate" (depending on the entity that has rendered the decision) are submitted "to the regular appellate court or municipal appellate court within 30 days from the date of the decision". ${ }^{95}$ However, an appeal submitted by any landholder who has been served with an expropriation order may be admitted only if it is accompanied by "a document that proves the handover of the land to the urban or woreda administration". 96 Moreover, the complaint regarding the amount of compensation shall not delay the execution of an expropriation order. ${ }^{97}$

\section{The Need for Judicial Scrutiny in Title Deed Revocations}

Administrative law, inter alia, deals with the institutional procedures which should be followed by administrative agencies "in dealing with the public" in the course of their actions. ${ }^{98}$ It also includes "judicial (and to some extent

${ }^{93}$ Proclamation No. 455/2005, Art. 11(2).

${ }^{94}$ Id., Art. 11(1).

${ }^{95}$ Id., Art. 11(4).

${ }^{96}$ Id., Art. 11(6).

${ }^{97}$ Id., Art. 11(7).

${ }^{98}$ Peter L. Strauss (2002). Administrative Law in the United States, Second Edition (Durham: Carolina Academic Press), p. 147. 
political) review of those actions". 99 The mandate entrusted to administrative authorities in Ethiopia includes not only implementing the proclamations enacted by the parliament but also enables them to issue of enabling legislation (namely Council of Ministers Regulations). These clearly involve administrative and legislative functions. However, the latter (i.e. the legislative function) is an incidental role because the issuance of regulations and directives is merely expected to serve an instrumental function in the implementation of the proclamation rather that stretching the scope and/or content of the latter.

Another aspect of administrative law relates to the tension between administrative decision-making and court judgments. As the latter is the task of courts, administrative entities are not expected to assume a judicial function in the guise of administrative decisions, with due respect to the vital role of administrative tribunals in resolving disputes (subject to the need for schemes of control such as judicial review).

The extent to which ambiguities and discretionary power are avoided in the demarcation lines between administrative and legislative functions, or between administrative and judicial functions determine the level of check and balance against abuse of authority by administrative entities. This balance ultimately determines the degree of the normative and institutional safeguard towards the protection of public interest and private rights as co-related and interdependent aspects of administrative responsibility and accountability. Unfortunately, however, Ethiopia has not yet enacted an administrative procedure law, a task which is long overdue.

The advantage of administrative tribunals relates to efficiency and effectiveness in contrast to judicial processes that might cause delay. However, experience in the complaints against expropriation and the amount of compensation show that equal attention ought to be given to the issue of impartiality through, for example, judicial review and stakeholder representation when members of administrative tribunals are appointed.

Most importantly, the notion of land use right ought to be given a wider definition, which should include what the landholder loses in terms of use right and the right to transfer the use rights through successions, sale, etc, which clearly goes beyond the fixtures (such as houses) on the land. Denial of economic value to land use rights adversely affects long-term investments, financial resources through collaterals and natural resource management. The narrow definition given to land use rights can be (as stated earlier) discerned from the lease proclamation $^{100}$ and from the expropriation proclamation $^{101}$

\footnotetext{
99 Ibid.

${ }^{100}$ Urban Lands Lease Holding Proclamation No. 721/2011.

${ }^{101}$ The Expropriation of Landholdings for Public Purposes and Payment of Compensation Proclamation No. 455/2005.
} 
although the Constitution does not, in principle, warrant such restrictive stipulations.

This problem in the conception of public property clearly influences the administrative decisions and awards of various administrative tribunals. It is further exacerbated by the legislative and adjudicative roles of executive offices in the course of allowing and withdrawing use rights. These discretionary powers can at times extend to a point of reluctance to implement court decisions.

There are a number of cases whereby regulatory offices revoked the validity of urban landholding certificates (after a court decision). ${ }^{102}$ This calls for

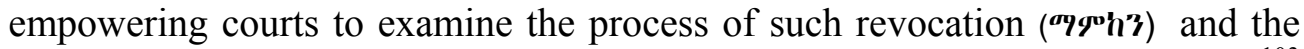
process of its initial issuance whenever a case involves such issues. ${ }^{103}$ Administrative entities are entitled to issue landholding certificates and also revoke them. Registration, verification and certification are done by the administrative entities. Courts should indeed be allowed to review the process to identify any form of impropriety in the case. ${ }^{104}$ There are encouraging developments in this regard because recent jurisprudence in the decisions of the Federal Supreme Court Cassation Division shows that courts are entitled to examine the legality in the procedures pursued by administrative organs in the issuance and revocation of landholding title deeds

In Taitu Kebede's Heirs v. Tirunesh et $a l,{ }^{105}$ the Federal Supreme Court Cassation Bench invoked Articles 1191-1198 of the Civil Code and held that 'the issuance of ownership certificates for immovable property should be in conformity with the proper legal procedures. Their revocation should also pursue legal procedures". ${ }^{106}$ It found that "The lower courts should have evaluated the evidence produced by both parties and they have thus erred in rejecting the claim of the petitioners solely based on the revocation of title certificate, and this is not consistent with the objectives and content of the Civil Code provisions indicated earlier". 107

\footnotetext{
${ }^{102}$ Focus Group Discussion, 13 July 2013, supra note 75.

${ }^{103}$ Ibid.

${ }^{104}$ Ibid.

${ }^{105}$ Taitu Kebede’s Heirs v. Tirunesh et al, (File No. 67011, 20 March 2012), Federal Supreme Court Cassation Division Decisions, Vol. 13, pp. 450-452.

${ }^{106}$ Federal Supreme Court Cassation Decisions, Vol. 13, pp. 450 - 452, Abridged Translation, EtLex, Vol. 1, Ethiopian Legal Information Consortium (December 2013), p. 258.

${ }^{107}$ Id., p, 260.
} 
Genet Seyoum v. Kirkos Sub-City Kebele 17/18 Administration et al ${ }^{108}$ clearly illustrates the conflict of interest involved when an administrative authority is allowed to revoke title deeds without judicial scrutiny. After the Federal First Instance court decided in favour of Dr. Genet based on her landholding certificate, the administrative authority revoked the certificate during the appellate litigation at the Federal High Court and argued that it has new evidence for the revocation of the landholding certificate thereby requesting dismissal of the case. The Federal High Court reversed the decision of the lower court based on the 'new evidence', i.e. revocation of the title certificate.

However the Federal Supreme Court Cassation Division decided that revocation of title certificate by the administrative organ while the litigation is underway shall not lead to the immediate dismissal of the case thereby holding that courts can examine the validity and legality of the revocation. It observed that the petitioner (plaintiff at the lower court) should have been given the opportunity to contest the validity of the revocation, and it remanded the case to the Federal First Instance Court so that it can examine the arguments and evidence of both parties and decide on the validity of the revocation. The Cassation Division held that:

$\ldots$ if the revocation of the title certificate is contested, decision should be given after examining whether the revocation is lawful, and the mere claim that the title certificate is revoked does not render it valid unless the issue is argued upon. The security of property rights enshrined in Articles 40(1) and 40(2) of the Constitution will be violated if it is held that the person whose holding certificate is revoked by an administrative organ does not have judicial recourse. ${ }^{109}$

Likewise, in Abadit L. v. Zalambesa Town Administration \& Berhane Z. ${ }^{110}$, Cassation File No. 48217 (13 October 2010), the Cassation Division of the Federal Supreme Court found that a statement of claim that is submitted to courts of law against the improper revocation of landholding and ownership of a house can be adjudicated by courts and that it shall not be regarded as a purely administrative task which falls outside the jurisdiction of courts.

This is a commendable trend which should be buttressed by consolidating judicial scrutiny, in the absence of which administrative powers will be trapped in a setting susceptible to discretion and abuse of authority. Although agencies

${ }^{108}$ Genet Seyoum v. Kirkos Sub-City Kebele 17/18 Administration et al, File No. 64014 (7 March 2012), Federal Supreme Court Cassation Decisions, Vol. 437-440.

${ }^{109}$ Federal Supreme Court Cassation Decisions, Vol. 13, pp. 437 - 440, Abridged Translation, EtLex, Vol. 1, Ethiopian Legal Information Consortium, (December 2013), p. 263.

${ }^{110}$ Abadit L. v. Zalambesa Town Administration \& Berhane Z., File No. 48217 (13 October 2010), Federal Supreme Court Cassation Decisions, Vol. 11, pp. 249 - 251. 
such as the Ombudsman, ${ }^{111}$ strong anti-corruption laws, ${ }^{112}$ and institutions in charge of enhancing the protection of human rights (which includes the right to property $)^{113}$ are meant to harness and control various infringements of the law including abuse of authority by administrative entities, the strength and impact of such schemes are largely contingent upon the promulgation and implementation of administrative procedure law that determines the legal bounds and accountability of administrative bodies. Such law is, inter alia, expected to address the root causes of the problems related with (a) the administrative entities and procedures in decision making; (b) complaint procedures in the course of protecting the rights, (c) rule making to apply (and not to alter) the laws enacted by the legislature; (d) enforcement of court decisions; (e) administrative hearings and their enforcement, and (f) prospects of judicial review if complaint is lodged against the decisions of administrative tribunals or after exhaustion of 'administrative remedies'.

\section{The Tension between Lease Sales and Municipal Functions}

\section{1- Conventional municipal services}

A century ago, Maltbie used memorable words to state the fundamental change in the functions of municipalities of modern cities. He wrote: "The old city was the sovereign of its people. The new city is their servant". ${ }^{114}$ The primary function of municipalities, inter alia, relate to urban planning, water and energy supply, drainage and sewerage, waste management, urban transport, roads, street lighting, parking areas, community health, education, protection of environment, markets, slaughterhouses and other functions. ${ }^{115}$ Municipalities and townships in Ethiopia were given similar functions since the enactment of Proclamation 4/7 $(1945)^{116}$, as amended by subsequent laws. Article 4(iii)(a) of the Proclamation, inter alia, states tasks of municipalities as:

... keeping of streets, squares, bridges, promenades and gardens, ...; schemes affecting sewerage, alignment of buildings, and generally the

${ }^{111}$ Institution of the Ombudsman Establishment Proclamation No. 211/2000.

${ }^{112}$ Revised Anti-Corruption Special Procedure and Rules of Evidence Proclamation No. 434/2005.

${ }^{113}$ Ethiopia Human Rights Commission Establishment Proclamation No. 210/2000.

114 Milo Roy Maltbie (1900) Municipal Functions. [In Review by: Delos F. Wilcox Source: Political Science Quarterly, Vol. 15, No. 2 (Jun., 1900)] p. 335.

${ }^{115}$ See for example, the Constitution of the Republic of South Africa 1996 (Act No. 108 of 1996); Art. 156 (Powers and functions of Municipalities), Chapter VI of the Mizoram Municipalities Act, 20017 (As amended in 2009), India, and other legal instruments that state functions of municipalities.

116 Consolidated Laws of Ethiopia, Vol. 1 (Faculty of Law, HSIU), 1972 , p. 133-135. 
whole of town public services such as water, light, paving of roads, cleansing, market areas, cemeteries slaughter houses and drains, theatres all public houses and baths and anything that is likely to contribute to the embellishment and the cleanliness of the town.

Sub-articles ' $\mathrm{b}$ ' to ' $\mathrm{f}$ ' of the provision further provide that municipalities and townships in Ethiopia shall offer fire safety services, poverty alleviation, hospitals, mental asylums, schools and other municipal welfare institutions, town health and hygiene services (not provided by the Ministry of Public Health), urban planning for buildings, large repairs, demolitions, the width level and construction of any new roads and generally for all works to be undertaken by private individuals.

These conventional activities of municipalities are similar in various countries. For example, municipal functions of cities in $\mathrm{USA}^{117}$ include urban planning and the "regulation of land-use and construction of buildings". This regulatory function of municipalities clearly relates to the task of designing the master plans and the regulatory function of ensuring that land use and construction of buildings are conducted in accordance with the master plan. Other functions of US municipalities include municipal functions related to roads, bridges, water supply, public health, primary education, primary health care, sanitation, waste management, fire services, urban forestry, provision of urban amenities and facilities (such as parks, gardens, playgrounds), burials and burial grounds, cremations, vital statistics (including registration of births and deaths), street lighting, parking lots, bus stops and public conveniences, regulation of slaughter houses and tanneries, and the protection of the environment and the promotion of cultural, education and aesthetic aspects. ${ }^{118}$ Moreover, municipalities pay particular attention to slum improvement and upgradation, urban poverty alleviation, safeguarding the interests of weaker sections of society, including the handicapped and the mentally retarded. ${ }^{119}$

The argument that is usually raised by municipal authorities in Ethiopia relates to the challenges of increasing urban population. However, this factor has not led to scenarios of role conflict in countries such as India where there is a graver pressure of urban overpopulation. For example, Section 57 of Chapter VI of the Mizoram Municipalities Act, 2007 (as amended in 2009) India, contains list of powers and functions of the municipality nearly similar to the ones stated above. In addition to water supply, drainage, sewerage and solid waste management, the list includes:

\footnotetext{
${ }^{117}$ See $<$ http://municipal.uslegal.com/powers-functions-and-duties-of-municipality $>$, accessed 29 November, 2013.

${ }^{118}$ Ibid.

${ }^{119}$ Ibid.
} 
- communication systems including construction and maintenance of roads, footpaths, pedestrian pathway, transportation terminals, both for passengers and good, bridges, over-bridges, subway, ferries and inland water transport system",

- "transport system accessories including traffic engineering schemes, street furniture, street lighting, parking areas and bus stops",

- "community health and protection of environment including planting and caring of trees on road sides and elsewhere",

- "markets and slaughter house", and

- the "promotion of educational, sport and cultural activities, and aesthetic environment."

These municipal functions are performed in most cities by using "master plans, zoning, subdivision regulations, building codes, and other public policies to shape development" which are "normally adopted to help protect the urban and natural environment, gear infrastructure investments with development, and maintain and enhance property values ...". ${ }^{120}$

In cities where land is publicly owned, such as Singapore, the legal regime does not entrust the same administrative authority with the functions of land grants and municipal services:

The government [of Singapore] relies almost exclusively on the Central Provident Fund (CPF) scheme, a mandatory savings scheme to finance a range of different welfare services: housing, healthcare, insurance, tertiary education and retirement (Asher, 2004). On the supply side, the government is also directly involved in the provision of subsidized education and healthcare; the Housing and Development Board (HDB) has been the largest housing developer for the past three decades. That more than 85 percent of the resident population lives in HDB housing has been described by Pugh (1985) as a 'symbol of pride, of nationhood, of the political achievement of the People's Action Party, and of government benevolence towards the public interest'. ${ }^{121}$

Singapore has thus entrusted the Housing and Development Board (HDB) with the task of housing development which operates, under the Ministry of National Development (MND). The ministry is in charge of the direction and

${ }^{120}$ David E. Dowall and Giles Clarke (1996). "A Framework for Reforming Urban Land Policies in Developing Countries" Urban Management and Land, Policy Paper, The World Bank, p. 5.

${ }^{121}$ Sock-Yong Phang (2007). "The Singapore Model of Housing and the Welfare State", Housing and the New Welfare State : Perspectives from East Asia and Europe. (Research Collection School of Economics. Singapore Management University), p. 18. 
implementation of policies that are related to land use planning and infrastructure development. ${ }^{122}$

Land use grants in China can be obtained from the government or from land use right holders who are entitled to transfer, pledge or lease their rights. China's Ministry of Land and Resources (MLR) and the local Land Resource Bureaus (LRB) are in charge of overseeing land use grants and registration. The power to allocate land use rights is the mandate of land administration departments $^{123}$ that are specifically established for the purpose. Moreover, Chinese law allows the contribution of land use rights as shareholders capital contribution (based on asset appraisal) in various economic undertakings including joint venture with foreign investors. ${ }^{124}$ "China has, since the 1980s, separated land use rights from land ownership and opened up a new market track for the conveyance of land use rights to commercial users". ${ }^{25}$ A case in point is the amendment made to the Constitution of the Peoples Republic of China adopted at the First Session of the Seventh National Peoples Congress on 12 April 1988. The amendment made to Article 10 of the Constitution reads:

The fourth paragraph of Article 10 of the Constitution, which provides that "no organization or individual may appropriate, buy, sell or lease land or otherwise engage in the transfer of land by unlawful means," shall be amended as: "No organization or individual may appropriate, buy, sell or otherwise engage in the transfer of land by unlawful means. The right to the use of land may be transferred according to law."

This was meant "to legitimize the commercialization of land use rights". ${ }^{126}$ Lin and Ho state two significant implications of this major Constitutional amendment: "First, it effectively separates land ownership from land use rights. While urban land remains owned by the state, its use rights can now be granted or transferred to commercial users. Second, it introduces a new market track into China's land system and, together with the traditional plan track, gives rise to a dual-track land-management system". ${ }^{127}$

${ }^{122}$ Singapore Property Weekly Challenge 136, http://zaphibel.free.fr/web/gicwiki/index.php?title=Singapore_Property_Weekly_Ch allenge_136, Accessed : 5 October 2013.

${ }^{123}$ Article, 23, the Urban Real Estate Administration Law (1994).

${ }^{124}$ See for example China Briefing, Feb 19, $2014<$ http://www.chinabriefing.com/news/2014/02/19/obtaining-land-use-rights-for-fies-in-china.html $>$, Accessed : 24 September 2013.

125 George C. S. Lin and Samuel P. S. Ho (2005). "The State, Land System, and Land Development Processes in Contemporary China", Annals of the Association of American Geographers, Vol. 95, No. 2 (Jun., 2005), p. 411.

${ }^{126}$ Id., p. 420.

${ }^{127}$ Ibid. 
While the experience of municipalities in the US represents the practices in developed countries, the Indian experience shows that population pressure does not alter the nature of municipal services. The Singaporean and Chinese experience further indicates that public ownership of urban land does justify the denial of economic value of land use rights and the merger of land allocation powers with municipal functions.

\subsection{The tension between urban planning and leasing out land}

The Federal Urban Planning Institute Proclamation ${ }^{128}$ envisages "the state-of-the art urban planning principles, a system that would ensure a healthy and sustainable development of growing urban centers". ${ }^{129}$ The objectives of the proclamation include the achievement of a balanced urban system by way of preparing integrated urban plans that encompass socio-economic and land-use dimensions and that ensure plan-led development of urban centers that have strong linkages with their rural hinterlands and serve as centers of rapid development." 130

The elements of Article 5(4) of the Proclamation are the following:

a) balanced urban system through the preparation of integrated urban plans;

b) the embodiment of socio-economic dimensions in the plan;

c) the inclusion of land-use dimensions in the plan;

d) the need to ensure plan-led development of urban centers

- with strong linkages with rural hinterlands, and

- that serve as centers of rapid development.

The first and fourth elements, i.e., integrated urban plans and plan-led development require urban planning whose formulation, management and implementation are professional and objective. As discussed under Section 3.1, the Urban Planning Proclamation No. 574/2008 vests extensive powers on municipalities in the preparation, approval, implementation, revision and modification of urban plans (i.e. structure plans and local development plans). The function of the Federal Urban Planning Institute is to provide support to municipalities and other pertinent offices in capacity building ${ }^{131}$, research and consultancy $^{132}$, information support services ${ }^{133}$ and urban plan preparation

\footnotetext{
${ }^{128}$ Federal Urban Planning Institute Proclamation No. 450/2005.

${ }^{129}$ Id., Preamble, paragraph 2.

${ }^{130}$ Id., Art. 5(4).

${ }^{131}$ See the powers and duties of the Urban Planning Institute, Proclamation No. 450/2005, Art. 6(1)

${ }^{132}$ Id., Art. 6(2).

${ }^{133}$ Id., Art. 6(3).
} 
(which may include preparing urban plans upon the request of regions or urban centers or base maps that can be used in the preparation of urban plans). ${ }^{134}$

The basic principles ${ }^{135}$ of urban planning embodied in Proclamation No. 574/2008 (as highlighted in Section 3.1) include "the promotion of balanced and mixed population distribution;" "safeguarding the community and the environment"; "preservation and restoration of historical and cultural heritages"; "balancing public and private interests"; and "ensuring sustainable development". Further discussion has also been made in relation with elements that should be embodied in local development plans as stipulated under Article 11(3) of Proclamation No. 574/2008. This provision, inter alia, envisages zoning of use type, ${ }^{136}$ local streets and layout basic structure ${ }^{137}$, organization of transport system ${ }^{138}$, "green areas, open spaces, water bodies, and places that might be utilized for common benefits." 139

However, there is manifest tension between municipal functions vis-à-vis the motives involved toward leasing out urban land. For example, an office (in Addis Ababa City Administration) in charge of parks and open spaces might submit a proposal in favour of allocating a certain open site in the city for "green areas, open spaces, water bodies, and places that might be utilized for common benefits." On the contrary, another office under the same municipality might propose the lease sale of the same location to enhance "urban renewal and upgrading" $"$. Such conflicting positions result from the role conflict inherent in the powers of the Addis Ababa City Administration.

A case in point is the fate of locations such as the space next to Wabi Shebelle Hotel on the way to Mexico Square. While an office in charge of the city's transport facilitation might propose the need for transport terminal, the offices entrusted with the tasks of land banking and leasing out land might have earmarked lease sale revenue and may possibly propose the sale of the location to maximize annual lease revenue. Such role conflicts are exacerbated by the municipality's discretion to revise master plans "where the need arises"141 even before the expiry of the validity period of master plan.

Under these circumstances municipal authorities may tend to pay more attention to annual performance reports of enhanced revenue from leasing out land. This is so because reports on annual lease revenue might sound louder in

\footnotetext{
${ }^{134}$ Id., Art. 6(4).

135 Proclamation No. 574/2008, Art. 5, Sub-Articles 6 to 10.

${ }^{136}$ Id., Art. 11(3)(a).

${ }^{137}$ Id., Art. 11(3)(b).

${ }^{138}$ Id., Art. 11(3)(c).

${ }^{139}$ Id., Art. 11(3)(f).

${ }^{140}$ Id., Art. 11(3)(e).

${ }^{141}$ Id., Art. 22(3).
} 
reports than that of reporting the designation of certain locations for "green areas, open spaces, water bodies, and places that might be utilized for common benefits". The following illustrates this point:

[G]reen areas benefit societies and the environment by providing clean air, maintaining biodiversity, helping cities build cheaper and long lasting drainage systems, and keeping down the heat during dry seasons. Unfortunately that is not true for Addis Ababa. "The per capita distribution of green areas and parks in Africa's urban cities is 7 square meters, but Addis Ababa only has 0.3 square meter distribution of green areas and parks". ${ }^{142}$

Kumlachew underlines the need to enhance the greenery of the city which is hailed as "the diplomatic capital of Africa" and he also states the challenges in the accessibility of the city's parks and green areas to the general public. ${ }^{143}$ As Deininger et al duly observed:

... In Addis Ababa, there is lack of clarity regarding the roles of central administration and the 10 sub-cities in allocating land and administering rights over land. In one case, the complexity led to allocation of public use areas to construction and housing and commercial buildings. Although the municipality agency responsible for the management of parks and green areas in Addis Ababa belatedly identified trespass of its mandate, no action was taken, because construction had already begun. The fact that the allocating authority felt secure in its mandate to manage the concerned areas, together with the delayed and ineffective response by the agency that was by law responsible for making decisions, illustrate the extent to which mandates are confused and the effect on land governance. ${ }^{144}$

In view of its growing population, the per capita green space needed in Addis Ababa deserves due attention. The lease-sale rush is not only eco-unfriendly, but adversely affects long-term lease revenue because a significant number of high rise buildings are being constructed (without alignments) but as chains adjacent

${ }^{142}$ Emnet Assefa (2013). 'In Search of Greener Addis', Addis Standard, June 3, 2013, citing Dr. Kumlachew Yeshitila, Head of Ecosystem Planning and Management at the Ethiopian Institute of Architecture, Buildings, Construction and City Development (EiABC) of the Addis Ababa University, Presentation of a research paper at the Ghion Hotel entitled 'Green Areas and Parks in Addis Ababa' at a public debate organized by Forum For Social Studies (FSS) in collaboration with the British Council, March 22, 2013. See, http://addisstandard.com/in-search-of-a-greeneraddis/, accessed: 12 December 2013.

${ }^{143}$ Ibid.

144 Klause Deininger, Harris Selod, Anthony Burns (2012). The Land Governance Assessment Framework: Identifying and Monitoring Good Practice in the Land Sector, World Bank Publications, p. 96. 
to (and at the edge of) the main streets, in effect, hindering long-term block based street alignments that could have availed more land in the backyard interiors. This is clearly inconsistent with the third element identified above, under Article 5(4) of Proclamation No. 450/2005 i.e. the inclusion of land use dimensions in the plan.

Moreover, role conflict renders it difficult for municipalities to attain sound social objectives in the interest of children, the elderly, the disabled, etc, in accordance with Article 9(5) of the Addis Ababa City Charter Proclamation ${ }^{145}$ thereby hampering "the embodiment of socio-economic dimensions in the plan" which constitutes one of the elements under Article 5(4) of Proclamation No. $450 / 2005$. Needless to say, societies that aim and aspire into the future pay due attention to children, a factor which is clearly missing in the construction boom in Addis Ababa. To borrow a few phrases from Forest Whitcraft's poem, "One hundred years from now" what will matter most is not the "kind of car [a person] drove" or the "kind of house [he/she] lived in" ... but whether the person was "important in the life of a child". ${ }^{146}$

\subsection{Role conflict in the Addis Ababa City Charter}

Article 9 of the Addis Ababa City Charter Proclamation ${ }^{147}$ makes incidental reference to municipal functions and it rather focuses on executive, legislative and adjudicatory functions of the City Government. Article 9(1) states the objective of the City government to "maintain good governance in which effectiveness, transparency and accountability" prevail in order to "make the City one in which expedient and equitable municipal services and reliable security and social harmony are ensured." According to sub-Articles 5 to 8 of Article 9, the "City Government shall have the objectives to":

- "make the City a place where the well-being and comfort of residents are safely kept and particularly where children, women, the disabled, the elderly and other disadvantaged segments of society avail themselves of special support; " 148

- "bring about the city's speedy economic development through the encouragement and enhancement of investment and research;",149

- "make the City a centre of commerce and industry of the country;" 150 and

\footnotetext{
${ }^{145}$ Addis Ababa City Government Revised Charter Proclamation No. 361/2003.

${ }^{146}$ Forest E. Witcraft (1894 - 1967).

147 Addis Ababa City Government Revised Charter Proclamation No. 361/2003. Arts. 41(1)(h), 41(2)(c) and 66 of the Charter are amended by Proclamation No. 408/2004 Addis Ababa City Government Revised Charter (Amendment) Proclamation.

${ }^{148}$ Proclamation No. 361/2003, Art. 9(5).

${ }^{149}$ Id., Art. 9(6).

${ }^{150}$ Id., Art. 9(7).
} 
- "make the City a naturally balanced, clean, green and favourable spot through the prevention of environmental pollution". ${ }^{151}$

While Articles 9(5) and 9(8) clearly have social and environmental themes, Articles 9(6) and 9(7) have the objectives of speedy enhancement of investment and rendering the city center of commerce and industry. These objectives involve conflict of interests because a city which is a center of industry cannot avoid being immensely polluted. Speedy economic development which does not give due attention to social and environmental wellbeing is usually susceptible to trade-offs in favour of economic scores in spite of glaze, noise, overcrowding and pollution.

The balanced attainment of these objectives not only requires effective performance on the part of municipalities, but also envisages the schemes of checks and balance against the risk of giving primacy to one of the objectives to the detriment of the other. Striking the appropriate balance between these economic, social and environmental pursuits becomes possible only where there are checks and balance among authorities that are entrusted with the promotion of these pursuits. One of the pursuits can easily be over-emphasized to the detriment of the other if the same administrative authority undertakes all the pursuits. The risk under such circumstances is that the economic-growth-first paradigm (which gives primacy to economic growth and statistical scores) usually overshadows the social and environmental dimensions of sustainable development. Even worse, the adverse impact of this scenario is aggravated many fold under settings of corruption and rent seeking.

The extensive power and functions vested in the Addis Ababa City Government is apparent from the stipulations under Article 11 of the Addis Ababa Charter. Sub-Articles (f) to (i) of Article 11(2) provide the following:

Without prejudice to the general provisions set forth under Sub-Article (1) of this Article, the City Government shall have the powers and functions to:

(f) identify, determine and organize municipal services to be delivered at the level of the City, a sub-City and a Kebele; to provide efficient, effective and equitable services through the use of a variety of service delivery alternatives and the participation of the people and to ensure that a standardized, acceptable system of service delivery is in place;

(g) administer, according to law, the land and the natural resources located within the bounds of the City;

(h) administer, develop or [sell] the houses nationalized as per Government Ownership of Urban Lands and Extra Houses Proclamation No. 47/1975 and administered by the City Government as well as other houses which the City Government built or otherwise obtained lawfully;

${ }^{151}$ Id., Art. 9(8). 
(i) expropriate private property and/or clear and takeover land holdings designated as an object of public interest, subject to payment of commensurate compensation in accordance with the law.

Addis Ababa Municipality has the "the power to make laws and exercise judicial powers specifically conferred on it by [the] Charter as well as executive powers and functions over matters that have not specifically been included in the details of the powers and functions of the executive organs of the Federal Government". ${ }^{152}$ Its powers and functions also include the issuance and implementation of "policies concerning the development of the City" and the approval and implementation of "economic and social development plans". ${ }^{153}$ Moreover, Addis Ababa City Government has the power to "constitute the executive bodies of the City Government and to establish public enterprises, as legal entities, on its own or in partnership, as per applicable laws, with the private sector or other third parties". ${ }^{154}$ In particular, the powers embodied in Article 11(2), i.e. the power to administer urban land and resources ${ }^{155}$ which include land expropriation and land allocation (based on the Land Lease Proclamation), the power to "administer, develop or sell the houses" ${ }^{156}$, and the power to "expropriate private property and/or clear and takeover land holdings designated as an object of public interest"157 are susceptible to administrative discretion.

\subsection{The need for a coherent urban plan and neutral enforcement}

Urban planners forward various options. According to Goodchild, compact city planning minimizes "impact of urban development on the countryside". 158 However, he underlines that "the search for higher densities should not go so far as to endanger popular demands for a sense of spaciousness and greenery". ${ }^{159}$ Compact city planning is based on the assumption that "dense and concentrated cities will support the principles of sustainable development" ${ }^{160}$ by reducing the pressure on the outskirts of cities and facilitating more efficient transportation.

${ }^{152}$ Id., Art. 11(1).

${ }^{153}$ Id., Art. 11(2)(a), 11(2)(b).

${ }^{154}$ Id., Art. 11(2)(d).

${ }^{155}$ Id., Art. 11(2)(g).

${ }^{156}$ Id., Art. 11(2)(h).

${ }^{157}$ Id., Art. 11(2)(i).

${ }^{158}$ Barry Goodchild (1994). "Housing Design, Urban Form and Sustainable Development: Reflections on the Future Residential Landscape" The Town Planning Review, Vol. 65, No. 2 (Apr., 1994), p. 156.

${ }^{159}$ Ibid.

160 Erling Holden (2004)."Ecological footprints and sustainable urban form”, Journal of Housing and the Built Environment, Vol. 19, No. 1, Dimensions of housing and urban sustainability (2004), p. 104 
Proponents of the green city, on the other hand, advocate for "a more open type of urban structure, where buildings, agricultural fields and other green areas form a sort of mosaic-like pattern". As the physical environment influences wellbeing and human behaviour, supporters of the green city focus on aspects of happiness and development beyond the glittering aspects high rise towers.

The efforts of urban planners and designers in the pursuit of "vital and livable cities" are informed by "the spirit of the times" which "sometimes meant the promotion of zoned, single-use urban forms" while "at other times, it meant the pursuit of a compact, spatially mixed and intensively used city" depending on "their alleged social, cultural and economic advantages". ${ }^{161}$ Findings show that "urban compaction is not necessarily conducive to a more sustainable society" and "that greater emphasis should be put on how to determine which forms are suitable in a given locality". ${ }^{162}$

Adherents of the decentralized city forms argue against the congestion in compact cities, while the supporters of the decentralized concentrated urban form attempt to promote a synthesis. ${ }^{163}$ As Tomita ${ }^{164}$ et al noted:

[I]t can be concluded that research focusing on a single aspect, such as the relationship between energy efficiency and transport or energy and urban form, is not likely to generate a reliable basis for the conception of a sustainable city or region. ${ }^{165}$ As cities are different in form and structure because of factors such as topography, history, climate, and socio economic conditions etc., they cannot all fit the same formula when it comes to a question of a sustainable urban form. ${ }^{166}$

Cities are thus expected to pursue the models and sub-models that are suitable for their particular settings and circumstances. This is because "there are no simple answers and no appropriate models" which in effect requires specific

${ }^{161}$ Albertine van Diepen (2002). Book Review, "Achieving Sustainable Urban Form by Katie Williams; by Elizabeth Burton; Mike Jenks" Journal of Housing and the Built Environment, Vol. 17, No. 1, State and market: Governing low-income housing in Asia (2002), p. 93

${ }^{162}$ Ibid.

${ }^{163}$ Yasuo Tomita, Daisuke Terashima, Amin Hammad and Yoshitsugu Hayashi (2003), "Backcast Analysis for Realizing Sustainable Urban Form in Nagoya" Built

Environment, Vol. 29, No. 1, The Sustainable City: Transport and Spatial Development, p. 17

${ }^{164}$ Ibid.

${ }^{165}$ Ibid, citing Breheny, M.J. (ed.) (1992). Sustainable Development and Urban Form. London: Pion.

166 Ibid, citing Frey, H. (1999). Compact, decentralized or what? the sustainable city debate, (Chapter 2). In Designing the City. London: E \& FN Spon, pp. 23-35. 
proposals "to be tested on a case by case basis in the light of existing policy commitments and specific environmental and economic objectives". ${ }^{167}$

As indicated earlier, the preamble of Federal Urban Planning Institute Proclamation No. 450/2005 pledges to adopt "the state-of-the art urban planning principles" and it also envisages "a system that would ensure a healthy and sustainable development of growing urban centers". This is reiterated under the preamble and Article 5 of the Urban Planning Proclamation No. 574/2008 which, inter alia, underline the need for sound and visionary urban plans to carry out development undertakings that positively contribute toward the "general wellbeing of the community" and "the protection of natural environment" 168 with a view to ensuring sustainable development. ${ }^{169}$

As Alison Brown observes, "[t]he adoption of goals for sustainable urban development requires an assessment of the effect of development on both the natural and human environment" ${ }^{170}$. She further notes that this suggests "integrated approaches to urban development, which combine social, economic, and environmental considerations, to give equitable access to resources both within and between generations". ${ }^{171}$

In low- and middle-income countries, an important component of sustainable development strategies has been to find ways of increasing the access of low- income groups to land for shelter, by seeking more efficient use of land, or forms of tenure which improve the security of households. ${ }^{172}$ It is argued here, however, that land for shelter is only one facet of the land resource so crucial to low-income households, and that land for livelihoods or social interaction is equally necessary in contributing to quality of life. ${ }^{173}$

Brown thus underlines the need to balance land use for shelter and urban space because" $[t]$ he space immediately outside the house or shelter forms an extension of living space and a centre for social interaction". ${ }^{174}$ In the context of Ethiopia,

${ }^{167}$ Barry Goodchild (1994). "Housing Design, Urban Form and Sustainable Development: Reflections on the Future Residential Landscape" The Town Planning Review, Vol. 65, No. 2 (Apr., 1994), p. 156.

${ }^{168}$ Urban Planning Proclamation No. 574/2008, Paragraphs 1 and 3 of the Preamble.

${ }^{169}$ Id., Art. 5, Sub-Articles 6 to 10.

${ }^{170}$ Alison Brown (2001). "Cities for the Urban Poor in Zimbabwe: Urban Space as a Resource for Sustainable Development". Development in Practice, Vol. 11, No. 2/3 (May, 2001), p. 320.

171 Id., pp. 320-311, citing Haughton, G and C. Hunter (1994) Sustainable Cities, London: Jessica Kingsley.

${ }^{172}$ United Nations Centre for Human Settlements (UNCHS) [Habitat] (1996) An Urbanizing World: Global Report on Human Settlements, Oxford: OUP.

${ }^{173}$ Brown, supra note 153, p. 321.

${ }^{174}$ Id., Alison Brown, p. 320. 
the significance of urban space for traditional neighbourhood institutions such as Idir $^{175}$ is apparent.

Professor Mee Kam Ng states that gap in China's urban planning system "has led to considerable wastage of land resources and consequent environmental problems". She underlines the need for "the adoption of a sustainable urban planning system" which "will mean that the Chinese government cannot confine sustainable development to the technical arena and has to face the challenge of valuing costs and benefits of different development options to various stakeholders - an area in which the urban planning profession has much to offer". ${ }^{176}$ She further notes that "[a]s economic reforms intensify, urban planners realise that planning and allocating land resources are not just a science but also an art that involves intense politics". ${ }^{177}$ The question then becomes "whose values should be adopted in formulating a plan? And, is a legitimate and legally binding urban planning system in place to implement it? ${ }^{178}$

It is in the context of the professional thresholds and the intense involvement of various administrative interests that urban planning is designed and implemented. The challenges are graver in Ethiopia due to role conflict. Even if the Federal Urban Planning Institute ${ }^{179}$ under the Ministry of Federal Affairs is in charge of capacity building, information support, preparation of urban plan (upon request), etc., it is ultimately the Municipalities that are (as highlighted in Sections 3.1 and 5.2) entrusted with the functions of preparing, approving, implementing, modifying and revising master plans. Their power to generate revenue through land lease naturally nurtures the interest to lease out more urban land, and this conflicts with their role as custodians of the city's master plan which requires balancing economic, social and environmental concerns. In effect, the provider of land has the functions of master plan approval, implementation, and revision analogous to a scenario whereby a cashier orders payments and also audits the cash flows.

${ }^{175}$ Idirs are traditional grass-root institutions whose members render support during various events including times of difficulties such as mourning, participation in funerals, providing facilities such as tents, chairs, and other items during events of mourning, marriage and other occasions.

${ }^{176}$ Mee Kam Ng (2004). "The Role of Urban Planning in China's Sustainable Development", The Town Planning Review, Vol. 75, No. 4 (2004), p. iv.

${ }^{177}$ Ibid.

178 Id., p. iii.

${ }^{179}$ See, Proclamation No. 450/2005. It is usually refereed to as the National Urban Planning Institute in various documents including its website. 


\section{Reflections on the 'Problem Tree'}

The concept of the 'Problem Tree' (Solution Tree Analysis) lists down core problems observed in a given setting, phenomena or social reality. It then attempts to identify the cause and effect relationship among the problems identified. Moreover, causes (at various levels) that are articulated in a negative form are transposed into their positive variation so that they can become objectives and strategies towards solving the problems that are identified.

The core problems discussed in the preceding sections of this article show discretionary and arbitrary powers of municipalities in Addis Ababa along with conflicting roles in land allocation (in return for lease revenue) vis-à-vis other conventional municipal functions. This role conflict and discretionary authority occurs in the midst of gaps in judicial review and administrative procedural law.

In legal regimes where the sale of urban land rights are private pursuits, municipalities do not claim property rights over urban land and they merely undertake their municipal functions that include the preparation and management of integrated urban plans. In socialist economies such as the former Soviet Union (where urban land was public property), land grants were administrative; but the grants did not involve pecuniary benefit to the administrative authorities. ${ }^{180}$ In effect, role conflict did not usually exist because regulatory offices could not derive pecuniary benefit from the land grants.

The challenge of role conflict occurs in settings which strive to unduly pursue fragmented (rather than synthesized) merger of certain elements from the two systems. In Ethiopia's land use rights regime, such fragmented collation results from picking the 'administrative authority of land allocation' limb from the soviet model and combining it with the 'land use rights market' element from the market economy model. A holistic synthesis indeed requires that the lease revenue received from the 'transfer of land use rights' be paid to the dispossessed and not to municipalities. Lack of pragmatic synthesis not only displaces and impoverishes evictees, but also unduly motivates municipalities to enhance lease revenue through land allocation thereby eroding the neutrality and vision required in the formulation and implementation of urban plans.

The normative challenge relates to the tension between the general constitutional principle of public ownership of land which recognizes land use

${ }^{180}$ For example, the need for land pricing that was proposed by various economists in the former Soviet Union during the 1960s was rejected in an official statement. According to the 1968 statement on land allocation policy, land grants free of charge were stated as "one of the greatest achievements of the Great October Socialist Revolution". Report by Deputy F. A. Surganov, Chairman of Council of the U.S.S.R. Agricultural Committee. Pravda and Izvestia, 14 December 1968. [See Edgar M. Hoover and Frank Giarratani (1984). An Introduction to Regional Economics, (New York: Alfred A. Knopf), Chapter 6]. 
rights vis-à-vis the denial of economic value of land use rights in various proclamations and judicial decisions. The Constitution recognizes private property, and at the same time stipulates that land is public property. However, it recognizes use rights on land and leaves the particulars to be determined by law. The laws highlighted in the preceding sections do not per se deny use rights over land, but fail to recognize its economic value, and restrict the scope of its transfer in the event of expropriation and sale.

It is to be noted that ownership of a thing by a person (or entity) does not preclude another person's claim of use right on the same thing. The fact that land is publicly owned does not thus preclude the landholder from use right claims over the land (including pecuniary benefits). Problems attributable to the either/or dichotomy in the conception of public property is one of the root causes that lead to restricted interpretation of land use rights in Ethiopia.

Two polarized interests permeate this tension. On the one hand, there are push factors toward laizez faire windfall rent gathering by selling land obtained in the guise of 'real estate development' and 'investment projects' on which the holder might have made meager or no investment. On the other hand, there is a corresponding pull factor on the part of administrative agencies in over-reacting to this challenge and steadily narrowing down the scope of the ownership of land use rights.

It is in the midst of this setting that the normative and administrative restrictions of land use rights are tightening up their grips on all sectors of the society rather than aiming at specific targets. This merely squares the circle, and entrenches rent seeking and corruption because it does not solve the problem but rather steadily widens the extensive discretionary functions of administrative authorities; and meanwhile it marginalizes and suppresses the economic potential that is inherent in the tenure and security of land use rights and private sector development.

\section{Conclusion}

Policies have lifespan unless they go through the phases of renewal and reinvention. Such pursuits of policy renewal start with a very modest step, i.e. admission of a problem. On the contrary, the easier options of 'denial' and 'blame games' merely reinforce problems and meanwhile erode opportunities toward preventive and curative solutions.

Two major concerns emerge from the discussion in the preceding sections. The first concern emanates from to the meager size of the pie that trickles down to urban landholders upon expropriation. As Cernea observes "[e]xpropriation of land removes the main foundation upon which people's productive systems, commercial activities and livelihoods are constructed" and this constitutes 
"decapitalisation and pauperisation of displaced people, through the loss of both physical and man-made capital". ${ }^{181}$

The discretionary powers of municipal authorities in Addis Ababa in the assignment and revocation of land use rights, and their decisions of allocation to investors are, inter alia, influenced by revenue enhancement through land lease to the highest bidder. A rational regulatory pursuit towards efficiency, equity and the public good presupposes utmost attention to win-win mutual benefits in favour of investors, evictees and the public at large. On the contrary, however, municipal authorities seek a higher share from land lease revenue by squeezing down the compensation that reaches urban homeowners. In effect, municipal authorities do not pay evictees the amount received from the new leaseholder per square meter. It is to be noted that, the municipality is transferring the same land use right to the new investor, and whatever the investor is willing to pay is an amount which the evictee could have received from selling her/his house.

The need for 'efficiency' justifies allocation of land to a person who can make use of it with optimal level of utility. However, the equally important need for 'equity' requires that the evicted person be paid an amount which $\mathrm{s} / \mathrm{he}$ could have received from the sale of the immovable through open market at the time of the eviction. This is a win-win option for all parties in which evicted homeowners, the municipality and the public at large would benefit from. It is to be noted that whatever goes into the pockets of citizens beefs up the economy by enhancing their purchasing (or job creation) power and wellbeing.

We can foresee practical problems with regard to the investor's financial capability in paying market price for privately owned houses. This can emerge where the site to be reallocated to investors affects the property rights of a significant number of urban house owners. Such issues are administrative rather than legal, and can prompt viable schemes such as measures against holdouts, long-term payment deals, and the empowerment of urban homeowners to utilize their land use rights as capital contribution in new investment projects thereby becoming shareholders pro rata to the market value of their land use rights.

The second concern that emerges from the role conflict in the functions of municipalities relates to the risk of haphazard disfigurement of cities mainly owing to the role conflict between the functions of municipalities as custodians of master plans toward sustainable cities, vis-à-vis the conflicting interest of municipalities to sell out more land on leaseholds to the detriment of aligned wide streets, open spaces, green areas, riverbanks and other public needs. This is

${ }^{181}$ Michael M. Cernea (1995). "Understanding and Preventing Impoverishment from Displacement; Reflections on the State of Knowledge," [In Chris McDowell, Editor, Understanding Impoverishment: The Consequences of Development-induced Displacement (Berghahn Books, 1996)], p. 22. 
mainly attributable to the land banking function of municipalities which inherently conflicts with compliance standards of appropriate urban plans.

A case in point is the rush to maximize leased out plots adjacent to the main streets. Urban plans consider unfolding events in terms of decades and centuries. While rising population necessitates wider streets and wider pedestrian paths, the prospects of declining population, on the other hand, deserves more open spaces, balanced landscaping and relatively greener yards in front of buildings. Unfortunately, however, the current construction boom in Addis Ababa seems to be incongruent with both demographic scenarios, mainly because role conflict has blurred the long-term vision of municipal authorities onto the future.

Role conflict occurs when individuals or institutions encounter role expectations that are in conflict. Under such settings, the pursuance of one of the roles obstructs or at least compromises the accomplishment of the other function. Municipal authorities in Ethiopia have annual plans which include raising land lease revenue. They also evaluate their quarterly or annual performance on the basis of their achievements including lease revenue which in other words means area of land leased out during a given period. The 'success' of municipalities in their 'land allocation' function from 'land banks' does not thus prove the attainment of their conventional municipal functions as providers of public utilities and as custodians of public parks, urban green areas, open spaces, riverbanks and wider streets.

About two thousand years ago ${ }^{182}$ Juvenal (of Ancient Rome) had raised a pertinent question as to "who shall judge the judges?". ${ }^{183}$ This query was forwarded as a caveat against the risks of discretionary authority and abuse in the absence of checks and balance. The need to address the adverse impact of role conflict and discretionary authority in Addis Ababa's municipalities thus calls for the empowerment of homeowners through stronger, wider and more effective land use rights. Secondly, there is the need for the total alienation of the land allocation function from municipalities by vesting this power on another co-equal public entity independent from the City Administration (with due participation of stakeholders). A short-term option (until the role conflict is resolved) can be considering master urban plans (approved by Addis Ababa City Council) as law $^{184}$ that shall be effective for at least ten years ${ }^{185}$ unaltered by administrative decisions.

${ }^{182}$ Circa 100 AD.

183 "Quis juret ipsos Jures?"

184 This requires enactment in the city's official law gazette and adequate publicity in various media. This option has the downsides of rigidity and inadequate dynamism, which seems to be a lesser evil.

${ }^{185}$ According to Article 10 of the Urban Planning Proclamation No. 574/2008, the period of validity of structure urban plans is ten years. 